\section{Effectiveness of a Canal Brush on Removing Smear Layer: A Scanning Electron Microscopic Study}

Eleni Protogerou', Ioanna Arvaniti', Ioannis Vlachos², Marouan Georgios Khabbaz $^{1}$

\author{
'School of Dentistry, Department \\ of Endodontics, University \\ of Athens, Greece \\ ${ }^{2}$ Laboratory for Experimental \\ Surgery and Surgical Research \\ "N.S. Christeas", Medical School, \\ University of Athens, Greece
}

Correspondence: Protogerou Eleni, 81, Pentelis Street, 152 34, Halandri, Athens, Greece. Tel: +30-210746-1120, +30-210-746-1309. e-mail:e_protogerou@hotmail.gr

\begin{abstract}
This study evaluated the effectiveness of a highly flexible endodontic brush made of polypropylene canal brush (CanalBrush; Coltène) on smear layer removal from the canal walls when used according to the manufacturer's recommendations. Forty-four singlerooted mandibular incisors were prepared to apical size 30/0.06 and randomly divided into three groups $A, B$ and $C$, where the final irrigation regimen was $10 \mathrm{~mL} 17 \%$ EDTA and 10 $\mathrm{mL} 2.5 \% \mathrm{NaOCl}$ for group A, $10 \mathrm{~mL}$ EDTA, $5 \mathrm{~mL} \mathrm{NaOCl}$, CanalBrush for $20 \mathrm{~s}$ at $450 \mathrm{rpm}$ and $5 \mathrm{~mL} \mathrm{NaOCl}$ for group $\mathrm{B}, 10 \mathrm{~mL} \mathrm{NaOCl}$, CanalBrush and $10 \mathrm{~mL} \mathrm{NaOCl}$ for group C. One medium-sized CanalBrush was used for each root canal and all brushes were examined under the optical microscope after application to evaluate bristle deformation. Afterwards, roots were split longitudinally and the presence of smear layer was evaluated under a scanning electron microscope. Used brushes invariably exhibited bristle deformation. Group $\mathrm{C}$ exhibited the highest means of smear layer in all thirds. Comparing the apical thirds in all groups, there was no statistical difference between groups A and $B(3.64 \pm 0.48$ and $3.68 \pm 0.62$ respectively), while group $C$ exhibited significantly higher scores $(3.9 \pm 0.28)$ than the other two groups. In conclusion, the CanalBrush proved unable to remove smear layer from the instrumented root canals, when used according to the manufacturers' instructions.
\end{abstract}

Key Words: Canalbrush, chemomechanical preparation, EDTA, irrigation, smear layer.

\section{Introduction}

Endodontic treatment aims at eliminating or critically reducing the microbial load of root canal system and at removing inorganic remnants and organic tissues, which constitute a potential nutrient for microorganisms. This goal is reached by chemomechanical preparation, i.e instrumentation and irrigation.

Instrumentation, though, produces a 1-5 $\mu \mathrm{m}$ thick smear layer on the dentinal surface, consisting of dentin, predentin, pulpal remnants, odontoblast processes, irrigant remnants and bacteria, in infected teeth (1-5).

Although controversy exists among authors as to whether this layer should be removed or not, smear layer removal is proposed after chemomechanical preparation in previously infected root canals $(6,7)$, before placing intracanal medicaments (8) and before final obturation of the root canals (9). Recently, with the introduction of adhesive dentistry to endodontics, smear layer removal is indicated in combination with resin based sealers $(10,11)$.

In the past, several materials and methods have claimed to be successful in smear layer removal, such as chelating agents (EDTA, citric acid, etc), lasers, sonic and ultrasonic devices, all of them with conflicting results $(6,12-17)$.

Recently, a microbrush specifically fabricated for root canal cleaning has been introduced on the market. The CanalBrush (Coltène, Germany) is available in three sizes (small, medium and large), which correspond to apical diameter of 25, 30 and 40 respectively, according to the ISO classification. The manufacturer recommends this brush to be used in conjunction with $\mathrm{NaOCl}$ at a maximum speed of $650 \mathrm{rpm}$ for up to $30 \mathrm{~s}$.

To date, a small number of investigations have evaluated the cleaning efficacy of the CanalBrush. Garip et al. (18) examined root canal cleanliness using EDTA with or without the application of the CanalBrush. Other authors compared its effectiveness to ultrasonic devices (19), or studied its cleaning efficacy after having adjusted the CanalBrush to a sonic handpiece (20). However, none of the aforementioned studies strictly follows the manufacturer's instructions; thus, there is insufficient information concerning the usefulness of the CanalBrush in the clinical practice of Endodontics.

The purpose of this study was to evaluate the efficacy of the CanalBrush on smear layer removal from the instrumented root canals, when used according to the company's instructions. The null hypothesis was that the use of CanalBrush after completion of chemomechanical preparation, according to the manufacturers' instructions, contribute to obtain cleaner canal walls.

\section{Material and Methods}

Forty-four freshly extracted mandibular human incisors, stored in 10\% formalin, were radiographed in a buccoligual direction to ensure that they possessed one straight root 
canal. All teeth were decoronated to a standard root length of $10 \mathrm{~mm}$ using a diamond disc. Afterwards, a size $10 \mathrm{~K}$-file (Dentsply Maillefer, Switzerland) was inserted into the canal orifice until its tip became just visible through the apical foramen and the working length was established at $1 \mathrm{~mm}$ shorter than the actual root length $(9 \mathrm{~mm})$. Finally, a small amount of Carbowax (Dow Chemical Co, Midland, $\mathrm{MI}$, USA) was placed on each root tip.

Root canal instrumentation was performed with GT rotary files Series 20 and 30 (Dentsply/Maillefer), used with the handpiece of an Endo IT motor (Aseptico, Woodinville, WA, USA) with programmed torque control and speed settings, in a crown-down manner. Instruments 30/0.10, 30/0.08 and 30/0.06 were initially inserted to 2, 5 and 7 $\mathrm{mm}$ in the root canal, respectively. Apical preparation of the root canals was completed by a file sequence of 30/0.04, 20/0.08 and 30/0.06. Between each file change patency was confirmed by using \# $10 \mathrm{~K}$-file and irrigation with 2 $\mathrm{mL} 2.5 \% \mathrm{NaOCl}$ was performed.

At the end of the chemomechanical preparation, teeth were randomly divided into three groups $A$ and $B(n=15$ each) and $C(n=14)$ and irrigation with a $27 \mathrm{G}$ blind-ended needle was carried out in group A using $10 \mathrm{~mL}$ of $17 \%$ EDTA (Vista Dental Products, Racine, WI, USA) for $3 \mathrm{~min}$ followed by a $10 \mathrm{~mL}$ flush of $2.5 \% \mathrm{NaOCl}$. In group $B$ the canals were irrigated with $10 \mathrm{~mL}$ of 17\% EDTA for $3 \mathrm{~min}$ and then flushed with $5 \mathrm{~mL} 2.5 \% \mathrm{NaOCl}$, brushed with CanalBrush at $450 \mathrm{rpm}$ for $20 \mathrm{~s}, 2 \mathrm{~mm}$ from the working length and followed by a $5 \mathrm{~mL}$ flush of $2.5 \% \mathrm{NaOCl}$. In group $\mathrm{C}$ the irrigation protocol included $10 \mathrm{~mL}$ of $2.5 \% \mathrm{NaOCl}$, application of CanalBrush as in the afore-mentioned group and followed by another $10 \mathrm{~mL}$ flush of the same solution. All CanalBrushes were inserted to the working length. At the end, all experimental groups received a final $10 \mathrm{~mL}$ flush of
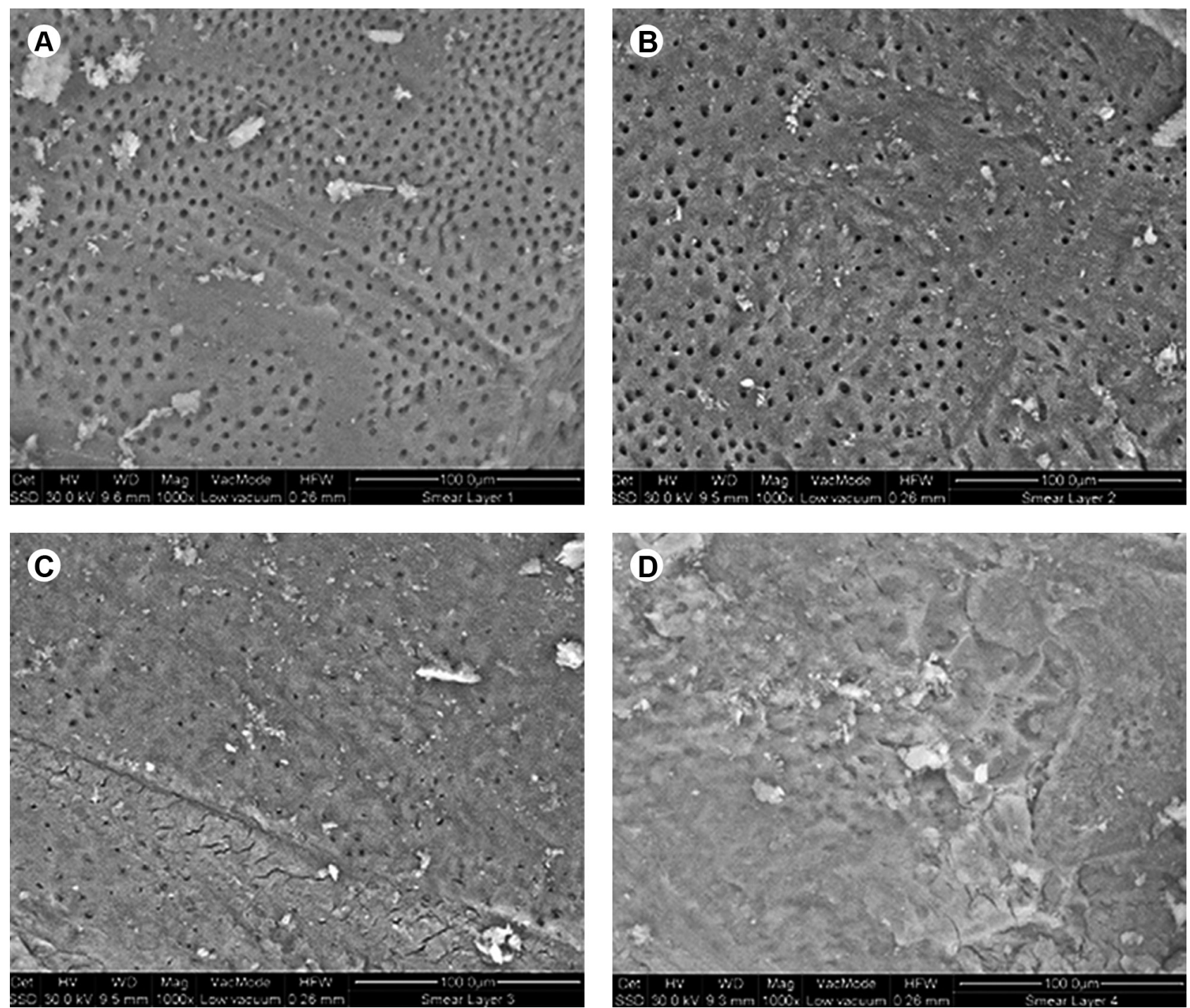

Figure 1. Representative SEM micrographs of the smear layer produced on canal walls prior to the conduction of the study. A: Score 1 . B: Score 2. C: Score 3. D: Score 4. 
saline to deactivate irrigant remnants. The total amount of irrigants used in each canal was $42 \mathrm{~mL}$. A new medium-sized CanalBrush was used for each root canal and all brushes were examined under the optical microscope after usage to evaluate bristle deformation. Afterwards, roots were split longitudinally with a diamond disk in a buccolingual direction. The presence of smear layer was evaluated by scanning electron microscopy (Quanta ${ }^{\mathrm{TM}}$ 3D DualBeamTM Hilsboro, Oregon, USA) at 1000x magnification using a 4-cathegory scoring system as follows: score 1 , smear layer covering $0-25 \%$ of the examined surface; score 2 , smear layer covering $25-50 \%$ of the examined surface; score 3 , smear layer covering $50-75 \%$ of the examined surface; and score 4, smear layer covering $75-100 \%$ of the examined surface (21).

Representative photos of each score taken in a pilot study were shown to the examiners before scoring (Fig 1). The scoring procedure was performed by 3 examiners and was double-blinded. First, the apical end of preparation was found at low magnification, and then every millimeter of the apical (0-3 mm), middle (4-6 $\mathrm{mm})$ and coronal (7$9 \mathrm{~mm}$ ) thirds of the root canal walls were scanned at $1000 \mathrm{X}$ magnification and scored (21).

Intraclass Correlation Coefficient (ICC) was calculated in order to assess the degree of agreement between observers, since our rating procedure employed multiple observers and considered ordinal data. ICC for single measure agreement was: $0.794(95 \% \mathrm{Cl} 0.76-0.82)$, and for the average of $\mathrm{k}$ measures: 0.92 (95\% $\mathrm{Cl} 0.91-0.93)$.

Data were expressed as mean \pm standard deviation (SD). Comparisons between more than two groups were performed by Analysis of Variance (ANOVA) and Welch's/ Brown-Forsythe robust tests. All tests were two-sided. Differences were considered as statistically significant if the null hypothesis could be rejected with $>95 \%$ confidence $(p<0.05)$.

\section{Results}

\section{Bristle deformation}

All used CanalBrushes invariably exhibited bristle deformation (Fig 2); however during the SEM examination no residues of those bristles were detected on the canals walls and no crushing was noticed.

\section{Smear Layer}

Mean scores for smear layer among groups in coronal, middle and apical thirds are presented in Table 1. Group $C$ exhibited the highest overall values and group $A$ the lowest. Regarding the apical third, no statistically significant difference was detected between groups $A$ and $B$, however results were significantly inferior in group $C$. Among root thirds, in group $A$, the coronal one had the lowest statistically significant score, while the apical third demonstrated the highest one. Group B exhibited the lowest score in the coronal third but no statistically significant difference was noted between middle and apical thirds. Group $\mathrm{C}$ showed no differences among thirds.

\section{Discussion}

The results of the present study did not show any improvement in smear layer removal when the CanalBrush was additionally used according to the manufacturer's

Table 1. Mean scores for smear layer in all groups for the coronal, middle and apical thirds.

\begin{tabular}{lccc}
\hline Root third & Group A & Group B & Group C \\
\hline Coronal, & $2.24 \pm 0.52^{\mathrm{a}}$ & $2.74 \pm 1.09^{\mathrm{d}}$ & $3.93 \pm 0.24^{\mathrm{g}}$ \\
Middle & $2.97 \pm 0.86^{\mathrm{b}}$ & $3.55 \pm 0.75^{\mathrm{e}}$ & $4.00 \pm 0.00^{\mathrm{h}}$ \\
Apical & $3.64 \pm 0.48^{\mathrm{c}}$ & $3.68 \pm 0.62^{\mathrm{f}}$ & $3.90 \pm 0.28^{\mathrm{f}}$ \\
\hline
\end{tabular}

c,f vs i, a vs b, b vs c, a vs c, d vs e, d vs f, a vs d, b vs e: statistically significant difference $(p<0.05)$
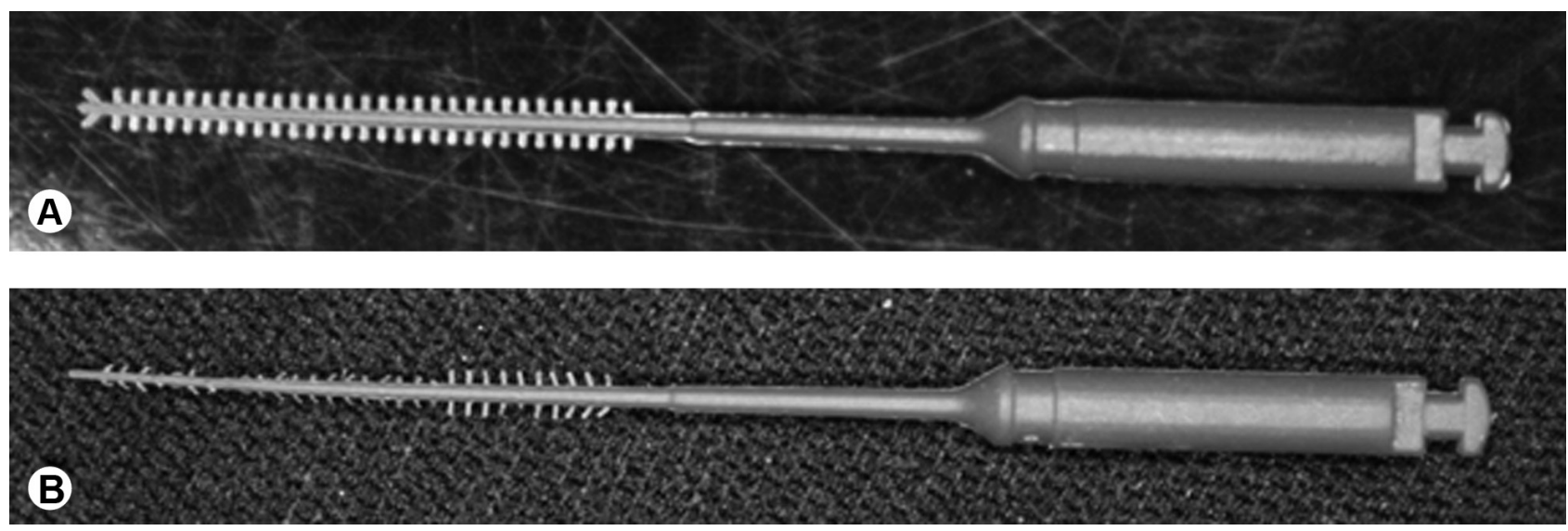

Figure 2. CanalBrush before (A) and after (B) rotation inside the root canal. Deformation of bristles is obvious. 
suggestions for the chemomechanical preparation of root canals. On the contrary, a worsening of the results was noticed, since smear layer scores were overall significantly higher in group $B$ (where the CanalBrush was used) when compared to group A. This was not the case for the apical third, where no significant difference in smear layer scores was noticed between groups A and B. No improvement in cleanliness has also been reported by Garip et al. 2010, where no significant differences were noted between groups with or without the use of the CanalBrush (18). Furthermore, Rödig et al. 2010 reported no significant differences for smear layer scores in the apical and middle thirds of root canals with or without the use of CanalBrush (19). The aforementioned studies, though, found insignificant differences between groups, which is not in line with the present finding, that the use of the CanalBrush significantly worsened the results.

The significantly higher scores that were obtained in the coronal and middle thirds in group B could be explained by the fact that, in contrast to previously published research (18-20) EDTA was not agitated with the CanalBrush within the root canals, since this was not included in the manufacturer's instructions. Another explanation of this discrepancy may be that previous studies advocated larger canal preparations in combination to the same or smaller CanalBrush sizes - 25/0.09 medium-sized CanalBrush (18) and 40/0.06, small-sized CanalBrush (19). It seems that the smaller canal preparation advocated in the present study (30/0.6) combined with the medium-sized CanalBrush (ISO: 30), although in line with company's suggestions (larger than the minimum preparation suggested for the medium sized canal brush), led to an early bristle deformation and "squeezing" inside the proportionally narrow root canal. This may have resulted in an intense friction of the brush against the root canal walls, recreating what had already been cleansed by the demineralizing action of EDTA.

Although smear layer scores were significantly higher in the coronal and middle third of Group B, compared to Group A, this was not the case for the apical third, where similar scores were noticed. This was probably due to the fact that the overall CanalBrush design is not tapered. So, a parallel-form instrument is forced to rotate into a tapered space as the instrumented root canal. This means that in the smallest diameter of the cone, i.e., the apical part of the root canal, the bristle deformation might be severe with an early cessation of its action on the canal walls, resulting in no additional action of the brush on the apical third in group B compared to group A. On the other hand, in the middle third, the brush will work more intensively with a less severe deformation that enhances friction against the canal walls, thus producing more smear layer as already stated. Probably larger canal preparations or smaller CanalBrush sizes, application of the brush with EDTA, changing the brush shape into an overall tapered design and creation of shorter bristles would allow the CanalBrush to work passively inside the root canal which may improve its performance. These hypotheses need to be proved before advising the CanalBrush for clinical use.

Although the combination of EDTA with $\mathrm{NaOCl}$ has long been known for its capacity for smear layer removal $(1,6,22)$, these solutions are not able to clean completely the apical third of the root canal (23-25). This is obvious in Groups $A$ and $B$, where the apical third exhibited significantly higher smear layer scores compared to the coronal third. Specifically in group $A$ the presence of smear layer follows an ascending pattern, while running from the coronal to the apical third, with statistically significant differences among thirds. However, in Group C where chemomechanical preparation was performed without using EDTA, more smear layer accumulated in all thirds of the root canals, despite application of the CanalBrush. This suggests that it is the action of the chelating agent that contributes to cleaner canal walls rather than the action of the brush.

Judging from the above mentioned findings, it seems that the brush itself may have a positive action for root canal cleanliness, but several factors should be considered; greater canal preparations or smaller CanalBrush sizes could let the brush passively work yielding probably better results. Another parameter not tested is time; increasing working time might enhance cleanliness. This would be beneficial only after having determined the optimal brush to canal preparation size ratio. Otherwise, increased working time might result in even higher smear layer scores if intense friction occurs for a longer period of time. Finally, it is possible that changing the brush into an overall tapered design would improve its performance.

From the above results, it may be concluded that the utilization of the CanalBrush according to manufacturer's recommendations did not contribute to produce cleaner dentinal walls. On the contrary, the traditional combination of EDTA and $\mathrm{NaOCl}$ proved superior to the CanalBrush in removing the smear layer.

\section{Resumo}

0 objetivo deste estudo foi avaliar a eficácia de um escova intra-canal (CanalBrush, Coltène) na remoção da smear layer das paredes do canal radicular, quando usada de acordo com as instruções do fabricante. Quarenta e quatro incisivos mandibulares unirradiculares foram instrumentados até o ápice com instrumentos 30/0.06 e aleatoriamente distribuidos em três grupos $A, B$ e $C$, com regime de irrigação final de 10 $\mathrm{mL}$ a $17 \%$ EDTA e $10 \mathrm{~mL} \mathrm{NaOCl}$ a 2,5\% para o Grupo A; irrigação final de $10 \mathrm{~mL}$ EDTA, $5 \mathrm{~mL} \mathrm{NaOCl}$, uso da escovinha CanalBrush por $20 \mathrm{~s}$ a $450 \mathrm{rpm}$ e $5 \mathrm{~mL} \mathrm{NaOCl}$ para o Grupo B e $10 \mathrm{~mL} \mathrm{NaOCl}$, uso da escovinha CanalBrush e $10 \mathrm{~mL} \mathrm{NaOCl}$ para o Grupo C. Foi utilizada escovinha CanalBrush de tamanho médio para cada canal e todas elas foram examinadas em microscópio para avaliação da deformação de cerdas. Depois as raizes foram cortadas longitudinalmente e a presença da smear layer foi avaliada por 
microscópio eletrônico de varredura. As escovinhas usadas apresentaram todas alguma deformação das cerdas. No Grupo $\mathrm{C}$ foi observada a maior média de área de smear layer em todos os terços dentais. Na comparação dos terços apicais de todos os grupos não houve diferença significativa entre os grupos $A$ e $B(3,64 \pm 0.48$ e $3,68 \pm 0,62$, respectivamente), enquanto que o Grupo $C$ mostrou escores significativamente mais altos $(3,9 \pm 0.28)$ que os outros dois grupos. Concluindo, a escovinha CanalBrush mostrou ser incapaz de remover a smear layer dos canais instrumentados, quando usada de acordo com as instruções do fabricante.

\section{References}

1. McComb D, Smith D. A preliminary scanning electron microscopic study of root canals after endodontic procedures. J Endod 1975;1:238-242.

2. Mader C, Baumgartner J, Peters D. Scanning electron microscopic investigation of the smeared layer on root canal walls. J Endod 1984;10:477-483.

3. Kochapan C. Die Bedeutung der Schmierschicht bei der Wurzelkanalbehandlung: Eine Ubersicht. Endodontie 1995;1:33-48.

4. Sen B, Wesselink P, Turkun M. The smear layer: a phenomenon in root canal therapy. Int Endod J 1995;28:141-148.

5. Torabinejad $M$, Handysides $R$, Khademi A, Bakland L. Clinical implications of the smear layer in endodontics. Oral Surg Oral Med Oral Pathol Oral Radiol Endod 2002;94:658-666.

6. Yamada R, Armas A, Goldman M, Lin P. A scanning electron microscopic comparison of a high- volume final flush with several irrigation solutions. Part III. J Endod 1983;9:137-142.

7. Olgart L, Brannstrom M, Johnson G. Invasion of bacteria into dentinal tubules. Experiments in vivo and in vitro. Acta Odont Scand 1974;32:61-70.

8. Goldberg F, Abramovich A. Analysis of the effect of EDTAC on the dentinal walls of the root canal. J Endod 1977;3:101-105.

9. Wennberg A, Orstavik D. Adhesion of root canal sealers to bovine dentine and gutta-percha. Part 2. Int Endod J 1990;3:13-19.

10. Eldeniz AU, Erdemir A, Belli S. Shear bond strength of three resin based sealers to dentin with and without the smear layer. J Endod. 2005;31:293-296.

11. de Mendonça AA, de Oliveira CF, Hebling J, Costa CA. Influence of thicknesses of smear layer on the transdentinal cytotoxicity and bond strength of a resin-modified glass-ionomer cement. Braz Dent J 2012;23:379-386.

12. Hülsmann $M$, Rümmelin $C$, Schäfers $F$. Root canal cleanliness after preparation with different endodontic handpieces and hand instruments: a comparative SEM investigation. J Endod 1997;5:301306.

13. Calt S, Serper A. Smear layer removal by EGTA. J Endod 2000;26:459461.

14. Di Lenarda $R$, Cadenaro $M$, Sbaizero 0 . Effectiveness of 1 mol L- 1 citric acid and 15\% EDTA irrigation on smear layer removal. Int Endod J 2000;33:46-52.

15. Torabinejad M, Khademi AA, Babagoli J, Cho Y, Johnson WB, Bozhilov $\mathrm{K}$, et al.. A new solution for the removal of the smear layer. J Endod 2003;29:170-175.

16. Marques AA, Marchesan MA, Sousa-Filho CB, Silva-Sousa $Y T$, Sousa-Neto MD, Cruz-Filho AM. Smear layer removal and chelated calcium ion quantification of three irrigating solutions. Braz Dent J 2006;17:306-309.

17. Uroz-Torres D, González-Rodríguez MP, Ferrer-Luque CM. Effectiveness of the EndoActivator System in removing the smear layer after root canal instrumentation. J Endod 2010;36,308-311.

18. Garip $Y$, Sazak H, Gunday M, Hatipoglu. Evaluation of smear layer removal after use of a canal brush: an SEM study. Oral Surg Oral Med Oral Pathol Oral Radiol Endod 2010;110:62-66.

19. Rödig $T$, Döllmann $S$, Konietschke $F$, Drebenstedt $S$, Hülsmann $M$. Effectiveness of different irrigant agitation techniques on debris and smear layer removal in curved root canals: a scanning electron microscopy study. J Endod 2010; 36:1983-1987.

20. Salman MI, Baumann MA, Hellmich M, Roggendorf MA, Termaat S. SEM evaluation of root canal debridement with Sonicare CanalBrush irrigation. Int Endod J 2010;43:363-369.

21. Arvaniti IS, Khabbaz MG. Influence of root canal taper on its cleanliness: A scanning electron microscopic study. J Endod 2011;37:871-874.

22. Goldman M, Goldman L, Cavaleri R, Bogis J, Peck S. The efficacy of several endodontic irrigating solutions: a scanning electron microscopic study. Part 2. J Endod 1982;8:487-492.

23. Ciucchi B, Khettabi M, Holz J. The effectiveness of different endodontic irrigation procedures on the removal of the smear layer: a scanning electron microscopic study. Int Endod J 1989;22:21-28.

24. O'Connell M, Morgan L, Beeler W, Baumgartner C. A comparative study of smear layer removal using different salts of EDTA. J Endod 2000;26:739-743.

25. Scelza M, Antoniazzi J, Scelza P. Efficacy of final irrigation: a scanning electron microscopic evaluation. J Endod 2000;26:355-358.

Received June 17, 2013

Accepted October 22, 2013 